\title{
Drastic changes called for in French space programme
}

Paris. French space policy is badly managed and lacks direction, and its four-fold growth in the past decade threatens the health of other areas of research. That is the conclusion of a report issued earlier this month by the Comité National d'Evaluation de la Recherche (CNER), formed to evaluate the country's research efforts. It says that what is needed is a parliamentary debate on space policy, greater emphasis on research, better financial and scientific management of existing programmes and increased accountability to the scientific community.

The crisis in French space, the world's third largest programme and the driving force behind European efforts in the field, stems from a decision by the French space agency Centre National d'Etudes Spatiales (CNES) to include manned space flights and a space station in its programme. That decision helped its budget to grow from FF2.1 billion (US\$400 million) in 1982 to FF9.2 billion next year, but it left little for other agency programmes. Similarly, CNES's increasing share of the civilian research budget - from 6.4 per cent in 1982 to 18 per cent next year - has squeezed out other worthy projects.

The problem may be alleviated next month if the European Space Agency, as is expected at a ministerial meeting in Granada, Spain, abandons its plans for an independent European space programme. But CNER is equally concerned about the origins of the problem, and how to prevent it from recurring.

The committee, created in 1989 by France's research minister, Hubert Curien, emphasizes the government's lack of control over space policy and the agency's poor handling of its finances and its research portfolio. Despite being the largest item in the research budget, space research has lacked a coherent strategy. Important decisions are made at various levels within the government, and two supervisory bodies formed in 1988 to improve the situation lack clear terms of reference and rarely meet.

Among other deficiencies, the committee could find no written record of the country's decision in 1985 to build Hermès, for instance, and a programme conceived as a single research satellite, SPOT 1 , has somehow grown into a series of four commercial satellites. The SPOT programme is still being funded through the research budget and, despite costing FF8 billion, "nobody knows if the government ever wanted it".

One necessary change would be to form

a powerful space committee within the government to bring CNES under executive control. A second remedy would be simpler accounting procedures allowing the agency's costs to be compared with the rest of civilian research spending. Specifically, the committee wants to end the practice of using the civilian research budget to fund such items as the METEOSAT satellite and road

French space spending takes off

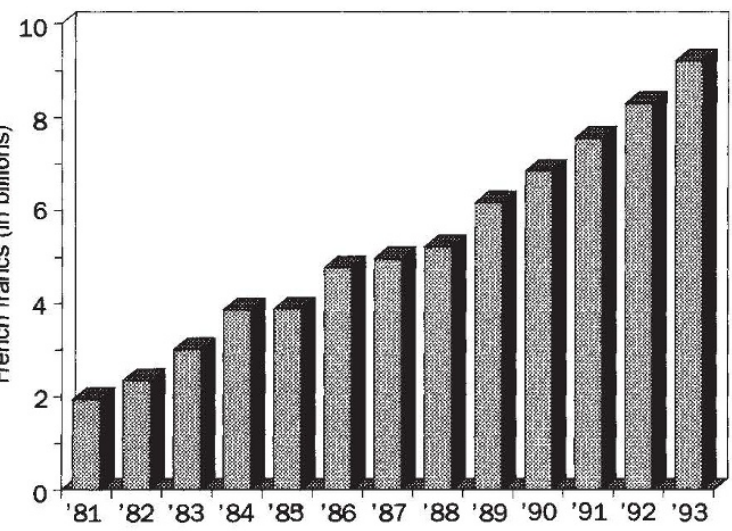

ource: French Ministry of Research and Space

construction at the agency's launch centre in Guyana.

The committee criticizes the agency for failing to recruit new talent to offset an ageing research staff and being too willing to follow the lead of the United States with such projects as Hermès and Columbus. It recommends that $\mathrm{CNES}$ pays greater attention to such technologies as new launch

systems, computing, artificial intelligence, robotics, electronics and the automation of space activities. The committee also questions the wisdom of going ahead with a heavy solid-fuel booster rocket, Ariane V (FF2.7 billion in 1993), designed chiefly to serve the Hermès project, and recommends instead that CNES revives the Ariane IV rocket, which it believes is better suited for both scientific and commercial launches.

Although Ariane is a notable success, CNES has also had many failures. Facing competition from France Telecom in 1988, CNES pressured companies and banks into supporting a risky venture to develop a commercial position locator system called LOCSTAR. The company went out of business last year after losing FF700 million.

The report also suggests that CNES reduces its industrial activities and return to its research roots. Towards that end, the committee recommends that CNES relinquishes its role in mature telecommunications and and meteorological projects to commercial companies and give up its one-third share in Arianespace.

The evaluation committee has no power to enforce its recommendations but it intends to pursue the issues raised in its report. Neither CNES nor the Ministry of Research and Space will comment, but Christian Bécle, president of CNER, says that the report's findings have "moved" the research ministry and that changes are inevitable.

Decian Butler

\section{NASA carves up science programme}

Washington. The administrator of the US National Aeronautics and Space Administration (NASA), Daniel Goldin, took the science community by surprise last week by splitting the space agency's science office in two and shunting aside its popular chief, Lennard Fisk.

The upheaval is part of Goldin's effort to lower costs, improve quality and reduce the time it takes to launch spacecraft (see Nature 358, 701; 1992). He also wants to bring civilian-minded NASA closer to the military, which is eager to place its sophisticated sensors aboard the agency's science satellites.

The reshuffling is more than rearranging the deck chairs on the ship of a sinking Republican administration. While big changes have been expected since Goldin took over in April, the reorganization raises more questions than it answers - and the confusion is not likely to subside until next year. If George Bush loses the election, Goldin's plans could evaporate if Bill Clinton wants a new NASA administrator. But Clinton could also decide first to see if Goldin's plans succeeds.

One uncertainty is that of where NASA's life and materials sciences programmes fit in this regime. Understanding how people function in space is now NASA's primary justification for the space station, and manufacturing flawless crystals and other materials in space is said to be the major industrial application of the station. Yet these two areas are yet to be reassigned. They could 